\title{
The Use of Bubble CPAP and Humidified High Flow Nasal Cannula Oxygen Therapy in Children with Severe Pneumonia and Hypoxemia: A Systematic Review of the Evidence
}

Mohammod Jobayer Chisti ${ }^{1}$, Trevor Duke 2 , Tahmeed Ahmed ${ }^{3}$, K.M. Shahunja ${ }^{4}$, Abu SMSB Shahid ${ }^{5}$, Abu Syed Golam Faruque ${ }^{6}$, Hasan Ashraf', Pradip Kumar Bardhan ${ }^{8}$, Stephen M. Graham9, Mohammed Abdus Salam ${ }^{10}$

\begin{abstract}
Background: Among children with severe pneumonia hypoxemia is the commonest complication leading to death. Some children will have both type I (hypoxemic) and type II (hypercarbic) respiratory failure. Together this accounts for high case-fatality rates in most populations with severe pneumonia. Standard oxygen supplementation by nasal prongs (low flow) can be lifesaving, but is not always sufficient to manage respiratory failure. In recent years continuous positive airway pressure (CPAP) has been used to relieve hypoxemia and reduce the work of breathing. There are several ways to give positive airway pressure; one is bubble CPAP (BCPAP), another is high flow nasal cannula (HFNC) oxygen therapy.

Objective: To review the evidence for using BCPAP, and HFNC therapy in children with severe pneumonia and hypoxemia, particularly the experience of these therapies in developing countries.

Methods: Two of our study investigators independently conducted searches of the existing literature in PUBMED in October 2014 to identify reports focusing on the use of BCPAP or HFNC therapy in children with severe pneumonia and hypoxemia, as defined by the World Health Organization.

Results: 13 relevant studies were identified. Ten evaluated the efficacy of BCPAP among 3164 children, and three described the same for HFNC in 255 children. In all studies the entry criteria was severe respiratory distress. The study methodologies, the outcomes recorded and results were heterogeneous. The age range of the children in the studies was from the immediate newborn period on day 1 of life up to the age of 12 years. However, we evaluated the outcome of our review in two aged categories and found: children 0-28 days for 8 studies and $>28$ days for 2 studies. In 3 studies of children aged 0-28 days and 2 studies of older children had clinical features consistent with severe pneumonia and those who among them were treated with immediate BCPAP therapy had better outcome $(p<0.01$ or $C I$ $<1)$ compared to those who were treated with delayed BCPAP, or historical control one each, or standard flow flow (LF) oxygen therapy (in two studies). Primary outcomes were comparable between BCPAP and ventilator driven CPAP in three studies and between BCPAP and low flow oxygen or variable flow nasal CPAP in two studies $(95 \%$ CI contain 1) of children aged 0-28 days. Children treated with HFNC compared to those who did not receive HFNC in three relevant studies, all of them in older children had better outcome $(p<0.05)$.

Conclusion: Studies of BCPAP and HFNC are heterogeneous with different populations, comparators, outcome measures and results. However limited studies suggest that BCPAP may be effective in managing respiratory distress and hypoxemia in developing countries, although evidence is not overwhelming. Studies of the use of HFNC therapy are more limited and do not allow firm conclusions to be made. Most studies of BCPAP and HFNC have been done in neonates with respiratory distress, and studies outside this age group, where the predominant pathologies are bacterial pneumonia, sepsis and viral bronchiolitis are needed.
\end{abstract}

KEY WORDS: Bubble CPAP, bronchiolitis, children, developing country, high flow nasal cannula, hypoxemia, neonates, severe pneumonia.

Introduction

Pneumonia and hypoxemia: Hypoxemia is a common and

1. Dr. Mohammod Jobayer Chisti, MBBS, MMed (Paed), Scientist \& Clinical Lead, ICU a, b

2. Dr. Trevor Duke, MD, FRACP, Professor Pediatrics and Pediatric Intensivist, Director ${ }^{\mathrm{C}}$

3. Dr. Tahmeed Ahmed, MBBS, PhD; Director ${ }^{\mathrm{b}}$

4. Dr. K.M. Shahunja, MBBS, Medical Officer ${ }^{b}$

5. Dr. Abu SMSB Shahid, MBBS, Medical Officer ${ }^{b}$

6. Dr. Abu SG Faruque, MBBS, MPH, Consultant ${ }^{\text {a }}$

7. Dr. Hasan Ashraf, MBBS, MCPS, MD, Senior Scientist \& Clinical Lead, ARI Ward ${ }^{\mathrm{a}, \mathrm{b}}$

8. Dr. Pradip Kumar Bardhan MBBS, MD, Scientist \& Chief Physician ${ }^{\mathrm{a}, \mathrm{b}}$

9. Dr. Stephen M. Graham, MD, FRACP, PhD, Professor of Pediatrics ${ }^{d}$

10. Dr. Mohammed Abdus Salam, MBBS, Director ${ }^{\mathrm{e}}$ a. Clinical Service (CS), International Centre for Diarrhoeal Disease Research, Bangladesh (icddr,b), Dhaka, Bangladesh

b. Centre for Nutrition \& Food Security (CNFS), icddr,b, Dhaka, Bangladesh

c. Centre for International Child Health, The University of Melbourne Department of Paediatrics and Murdoch Childrens Research Institute, Royal Children's Hospital, Melbourne, Australia

d. International Union Against Tuberculosis and Lung Disease, Paris, France

e. Research \& Clinical Administration and Strategy (RCAS), icddr,b, Dhaka, Bangladesh

Corresponding Author

Dr. Mohammod Jobayer Chisti, Scientist, CNFS \& Clinical Lead, Intensive Care Unit \& Consultant Physician, ARI ward; Dhaka Hospital, icddr,b; 68 Shaheed Tajuddin Ahmed Sarani, Mohakhali, Dhaka 1212, Bangladesh E-mail: chisti@icddrb.org 
serious complication in children with pneumonia. Hypoxemia is defined by WHO as a reduction of less than $90 \%$ arterial oxygen saturation measured by pulse oximetry ${ }^{1}$. Hypoxemia is estimated to occur in $13 \%$ of all cases of pneumonia presenting to health facilities ${ }^{2}$, and is the major risk factors for death in pneumonia ${ }^{2-4}$. Among the estimated 7.6 million global deaths in children under five in 2010, pneumonia accounted for $18 \%$ of the deaths ${ }^{5}$. In the same year there were an estimated 180,000 deaths in children under 5 years of age in Bangladesh, $14 \%$ of these deaths were due to pneumonia ${ }^{6}$.

\section{Different modes of respiratory support for children with} hypoxemia

Standard oxygen therapy, Bubble CPAP (BCPAP) and high flow nasal cannula (HFNC): Respiratory support for pneumonia can be achieved by various oxygen delivery methods. Low flow oxygen administration $(0.5$ to $2 \mathrm{~L} / \mathrm{min})$ is the conventional method ${ }^{7}$. When this fails the next level of respiratory support is often continuous positive airway pressure (CPAP). CPAP can be delivered in several ways: non-invasive or invasive continuous positive airway pressure or positive pressure ventilation (PPV). Among the non-invasive continuous positive airway pressure, BCPAP or HFNC therapy are now most commonly used in managing neonatal respiratory failure. BCPAP can be administered using a number of patient interfaces, including a tight-fitting face mask, nasal prongs, nasopharyngeal tube or endotracheal tube using a conventional ventilator or CPAP driver. HFNC therapy can also be administered using tight-fitting face mask, nasal prongs, blender machine, or CPAP driver.

The purpose of BCPAP/HFNC is to avoid airway collapse even during the expiration phase to improve oxygenation ${ }^{8}$. BCPAP or HFNC therapy can help to avoid the airway collapse by maintaining positive pressure in the alveoli which improves alveolar ventilation and oxygenation by increasing functional residual capacity, decreasing pulmonary edema, and minimizing expiratory bronchiolar collapse. The continuous flow of gas given throughout the respiratory cycle also assists in reducing the patient's work of breathing ${ }^{9,10}$.

\section{Objective}

The primary objective of this review was to evaluate the evidence for using BCPAP and HFNC oxygen therapy in children with severe pneumonia and hypoxemia particularly the experience of these therapies in developing countries.

\section{Methods}

We conducted a search of the existing literature to identify reports focusing on pneumonia, hypoxemia, BCPAP, and HFNC. We searched PubMed with no limitations. The search strategies and outcomes are summarized in Table 1. The initial searches were conducted in June 2013 and further searches in October 2014. All abstracts retrieved by the individual searches were reviewed. Full-text articles were retrieved and evaluated if the abstract suggested potential relevance. Some full-text articles were readily available in PubMed and those were not available in PubMed, retrieved though online "discovery search" from the library of the
University of Melbourne. Inclusion criteria were studies investigating the role of BCPAP or HFNC therapy in children having the clinical features of severe pneumonia and hypoxemia as defined by WHO. Excluded were reports that included animal models or respiratory distress syndrome (RDS) or used surfactant, or used CPAP or HFNC therapy only for post extubation support.

Table 1. Search strategy used to identify relevant publications and outcome for this review (for bubble CPAP and humidified high flow nasal cannula therapy)

\begin{tabular}{|c|c|c|c|c|}
\hline Database & $\begin{array}{l}\text { Strategy } \\
\text { and } \\
\text { keywords } \\
\text { used }\end{array}$ & $\begin{array}{l}\text { Total } \\
\text { number } \\
\text { of } \\
\text { matches }\end{array}$ & $\begin{array}{l}\text { Publications } \\
\text { relevant } \\
\text { for } \\
\text { review }\end{array}$ & $\begin{array}{l}\text { Year } \\
\text { of } \\
\text { publications }\end{array}$ \\
\hline Medline & $\begin{array}{l}\{(\text { bubble cpap) OR } \\
\text { (bubble continuous } \\
\text { positive airway } \\
\text { pressure) AND } \\
\text { ((child*) OR } \\
\text { (paediatric) OR } \\
\text { (Pediatric) OR } \\
\text { (infant*) OR } \\
\text { (neonate*)\} }\end{array}$ & 71 & 10 & 1991-2014 \\
\hline Medline & $\begin{array}{l}\text { ((high flow nasal } \\
\text { cannula) OR } \\
\text { (humidified high } \\
\text { flow nasal cannula)) } \\
\text { AND (neonate } \\
\text { OR Child*) }\end{array}$ & 91 & 3 & $1985-2014$ \\
\hline
\end{tabular}

*plural number

One of our study investigators helped me by performing independent searches in PubMed using the same search strategies. The outcome of both searches was the same and we did not have any dispute in finalizing the articles in our review.

Risk of bias in individual studies: Study quality was assessed using the Cochrane Collaboration risk of bias tool ${ }^{11}$. Two authors independently rated these criteria and were of the same agreement.

\section{Results}

The search retrieved 71 and 91 published studies for BCPAP and HFNC respectively in PubMed/Medline. Of these, 33 studies of BCPAP and 27 studies of HFNC were potentially relevant. The full texts of these studies were sought. Of the 59 articles retrieved, 40 were excluded: 23 on BCPAP ${ }^{12-34}$ and 24 on HFNC ${ }^{35-58}$ (Figure 1). Eventually 13 studies (10 for BCPAP) ${ }^{59-68}$ and 3 for HFNC ${ }^{69-71}$ ) from 8 countries fulfilled the criteria for the review (Table 2). 
Figure 1: Flow chart showing retrieval strategy and reasons for study exclusion

\begin{tabular}{|c|}
\hline \multicolumn{2}{|c|}{ Medline search } \\
\hline $\begin{array}{c}162 \text { published studies were found to be screened (71 and } \\
91 \text { published studies for BCPAP and HFNC respectively) }\end{array}$ \\
\begin{tabular}{|c|}
60 potentially relevant studies (33 and 27 full text articles \\
for BCPAP and HFNC respectively) were reviewed
\end{tabular} \\
\hline $\begin{array}{c}13 \text { articles (10 and 3 } \\
\text { articles for BCPAP and } \\
\text { HFNC therapy } \\
\text { respectively) were most } \\
\text { relevant }\end{array}$ \\
$\begin{array}{c}\text { 47 articles (23 and 24 } \\
\text { from BCPAP and } \\
\text { HFNC respectively) } \\
\text { were excluded* }\end{array}$ \\
\hline
\end{tabular}

*22 from BCPAP therapy ( 5 with respiratory distress syndrome, 5 post-extubated neonates, 4 neonates who used surfactant, 2 editorials, 2 case reports, and 5 review articles) and 24 from HFNC therapy (9 post-extubated neonates, 7 review articles, 2 case series, 2 articles involving surgical cases, 1 neonate who used surfactant, 1 had nebulised $3 \% \mathrm{NaCl}$ as comparison group, 1 article with ARDS cases, and 1 had no comparison group)

\section{Description of the included studies}

\section{BCPAP}

Among the 10 relevant publications for children treated with BCPAP, the age range of the study children was 4 hours to 12 years and the gestational age of newborns ranged from 26 weeks onwards (Table 2). Among these 10 studies 8 were found to have children aged 0-28 days and rest 2 had children 0-12 years (Table 2). Four publications included data from developed countries such as two from United States of America (USA) ${ }^{61,66}$, one each from United Kingdom (UK) ${ }^{67}$ and Australia ${ }^{64}$ while six other publications from developing countries such as three from India ${ }^{60,65,68}$, one each from Fiji ${ }^{63}$, Brazil $^{62}$, and 4 rural hospitals from Ghana (RCT) ${ }^{59}$ (Table 2).

All the ten studies were prospective and five among 0-28 days group $^{61,62,64-66}$ and one among $>28$ days group ${ }^{59}$ were RCTs. These 10 studies evaluated the efficacy of BCPAP involving 3164 children: 3059 in children aged 0-28 days and 105 children $>28$ days old. The study methodologies, the outcomes recorded and results were heterogeneous, although severe respiratory distress (severe dyspnea, or grunting or severe chest retraction and/or hypoxemia) was the common components of all these prospective studies. There were differences in the methods of analysis. Five studies in 0-28 days old ${ }^{62-65,67}$ reported the relative risk of main outcome variable and their $95 \%$ confidence intervals. Three studies, two in children $>28$ days ${ }^{59,60}$ and one in children $0-28$ days $^{68}$ reported only $\mathrm{p}$ values between groups and other two ${ }^{61,66}$ reported as "not significant" (Table 2). Children treated with BCPAP therapy compared to other forms of oxygen therapy (head box oxygen, historical control, delayed BCPAP, or conventional oxygen therapy) in four of these studies ( 2 in children $0-28$ days $^{63,64}$ and other in children $>28$ days $^{59,60}$ ) had better outcomes (Table 2). Primary outcomes were comparable between BCPAP and ventilator driven CPAP in three RCTs in children $0-28$ days old ${ }^{61,62,65}$. The primary outcomes of rest of the two studies treated with BCPAP oxygen therapy compared to low flow.

Table 2. Role of bubble CPAP in children with clinical signs of severe pneumonia

\begin{tabular}{|c|c|c|c|c|c|c|c|c|}
\hline Reference & Country & $\begin{array}{c}\text { Age } \\
\text { commencing } \\
\text { BCPAP }\end{array}$ & \begin{tabular}{|c|} 
Gestational \\
age \\
(weeks)
\end{tabular} & $\begin{array}{l}\text { Patient's } \\
\text { number } \\
\text { (Total) }\end{array}$ & $\begin{array}{c}\text { Type of } \\
\text { BCPAP/patient's } \\
\text { number }\end{array}$ & $\begin{array}{c}\text { Comparison } \\
\text { group } \\
\text { (patient's number) }\end{array}$ & $\begin{array}{c}\text { Main } \\
\text { outcome } \\
\text { variable }\end{array}$ & $\begin{array}{c}\mathrm{RR}(95 \% \mathrm{CI}) \\
\text { or } \\
\text { P value }\end{array}$ \\
\hline \multicolumn{9}{|c|}{ In children aged 0-28 days } \\
\hline $\begin{array}{l}\text { Daga S et al. } \\
(2014)\end{array}$ & India & $<7$ days & $\geq 32$ & 140 & $\begin{array}{l}\text { Nasal } \\
\text { prong (84) }\end{array}$ & $\begin{array}{l}\text { Standard flow } \\
\text { oxygen }(56)\end{array}$ & $\begin{array}{l}\text { Deaths [6 }(11 \%) \\
\text { vs. } 2(2 \%)]\end{array}$ & 0.04 \\
\hline $\begin{array}{l}\text { Heuvel et al. } \\
(2011)\end{array}$ & UK & 4-40 hours & $27-40$ & 25 & $\begin{array}{l}\text { Nasal } \\
\text { prong (5) }\end{array}$ & $\begin{array}{l}\text { Conventional } \\
\text { oxygen }(20)\end{array}$ & $\begin{array}{l}\text { Death }[2(40 \%) \\
\text { vs. } 14(70 \%)]\end{array}$ & $0.6(0.02-3.0)$ \\
\hline $\begin{array}{l}\text { Yagui et al } \\
(2011)\end{array}$ & Brazil & $>24$ hours & $32-39$ & 39 & $\begin{array}{l}\text { Nasal } \\
\text { prong }(20)\end{array}$ & $\operatorname{VCPAP}(19)$ & $\begin{array}{l}\text { CPAP failure [4 }(20 \%) \\
\text { vs. } 4(21 \%)]\end{array}$ & $1.0(0.3-3.3)$ \\
\hline $\begin{array}{l}\text { Courtney et al. } \\
(2011)\end{array}$ & USA & 4-28 days & $26-33$ & 18 & $\begin{array}{l}\text { Nasal } \\
\text { prong (13) }\end{array}$ & $\operatorname{VCPAP}(5)$ & WOB & NS \\
\hline $\begin{array}{l}\text { Tagare et al. } \\
(2010)\end{array}$ & India & - & $<37$ & 30 & ВСРАР (15) & $\operatorname{VCPAP}(15)$ & Success of ВСРCP & $1.1(0.8-1.5)$ \\
\hline $\begin{array}{l}\text { Buckmaster et al. } \\
(2007)\end{array}$ & Australia & $<24$ hours & $>30$ & 300 & $\begin{array}{l}\text { Hudson binasal } \\
\text { prong }(151)\end{array}$ & $\begin{array}{l}\text { Headbox } \\
\text { Oxygen (149) }\end{array}$ & $\begin{array}{l}\text { Treatment failure } \\
\text { [35 (23\%) vs. } 60(40 \%)]\end{array}$ & $0.6(0.4-0.8)$ \\
\hline $\begin{array}{l}\text { Koyamaibole et al. } \\
(2006)\end{array}$ & Fiji & $<28$ days & $34-40$ & 2488 & $\begin{array}{l}\text { Nasal } \\
\text { prong (1382) }\end{array}$ & $\begin{array}{l}\text { Historical } \\
\text { control (1106) }\end{array}$ & $\begin{array}{l}\text { Need for MV [70 }(5 \%) \\
\text { vs. } 113(10 \%)]\end{array}$ & $0.5(0.4-0.7)$ \\
\hline $\begin{array}{l}\text { Liptsen et al } \\
(2005)\end{array}$ & USA & $<28$ days & $<30$ weeks & 18 & ВСРАР (9) & $\begin{array}{l}\text { Variable flow } \\
\text { NCPAP }(9)\end{array}$ & WOB & NS \\
\hline
\end{tabular}


Bangladesh Crit Care J September 2014; 2 (2): 71-78

\begin{tabular}{|l|l|l|l|l|l|l|l|l|l|}
\hline Reference & Country & \multicolumn{1}{|c|}{$\begin{array}{c}\text { Age } \\
\text { commencing } \\
\text { BCPAP }\end{array}$} & $\begin{array}{c}\text { Gestational } \\
\text { age } \\
\text { (weeks) }\end{array}$ & $\begin{array}{c}\text { Patient's } \\
\text { number } \\
\text { (Total) }\end{array}$ & $\begin{array}{c}\text { Type of } \\
\text { BCPAP/patient's } \\
\text { number }\end{array}$ & $\begin{array}{c}\text { Comparison } \\
\text { group } \\
\text { (patient's number) }\end{array}$ & \multicolumn{2}{|c|}{$\begin{array}{c}\text { Main } \\
\text { outcome } \\
\text { variable }\end{array}$} & $\begin{array}{c}\text { RR (95\% CI) } \\
\text { or } \\
\text { P value }\end{array}$ \\
\hline $\begin{array}{l}\text { In children aged }>28 \text { days } \\
\text { Wilson PT et al. } \\
(2013)\end{array}$ & Ghana & $3-60$ months & - & 69 & $\begin{array}{l}\text { Hudson BCPAP } \\
\text { nasal cannula } \\
\text { imediately (31) } \\
\text { BCPAP (36) }\end{array}$ & $\begin{array}{l}\text { Hudson BCPAP } \\
\text { nasal cannula } \\
\text { delayed (38) } \\
\text { Before received } \\
(2011)\end{array}$ & $\begin{array}{l}\text { Change in respiratory } \\
\text { rate at } 1 \text { hour } \\
\text { of enrolment } \\
\text { Improvement } \\
\text { of vital signs }\end{array}$ & $<0.001$ \\
\hline
\end{tabular}

$\mathrm{BCPAP}=$ bubble CPAP; VCPAP = Ventilator derived CPAP $; \mathrm{WOB}=$ work of breathing; $\mathrm{MV}=$ mechanical ventilation; $\mathrm{NS}=$ not significant

oxygen or variable flow nasal CPAP therapy in children aged 0-28 days were also comparable ${ }^{66,67}$ (Table 2).

\section{HFNC}

Among the 3 relevant publications for children treated with HFNC therapy, none of the studies categorized the age limit as 0 -28 days and these 3 studies aged 0-12 years and involved 255 children. One of the studies originated from New Zealand ${ }^{69}$, one from $\mathrm{USA}^{70}$, and another study originated from Australia ${ }^{71}$.

Table 3. Role of humidified high flow nasal cannula in children with clinical signs of severe pneumonia

\begin{tabular}{|c|c|c|c|c|c|c|c|c|}
\hline Reference & Country & \begin{tabular}{|c} 
Age \\
commencing \\
HFNC
\end{tabular} & $\begin{array}{c}\text { Gestational } \\
\text { age } \\
\text { (weeks) }\end{array}$ & $\begin{array}{l}\text { Patient's } \\
\text { number }\end{array}$ & $\begin{array}{l}\text { Type of } \\
\text { HFNC/ } \\
\text { patient's } \\
\text { number }\end{array}$ & $\begin{array}{l}\text { Comparison } \\
\text { group } \\
\text { (patient's } \\
\text { number) }\end{array}$ & $\begin{array}{l}\text { Main } \\
\text { outcome } \\
\text { variable }\end{array}$ & P value \\
\hline \multicolumn{9}{|c|}{ In children with signs of severe pneumonia without bronchiolitis } \\
\hline $\begin{array}{l}\text { Spentzas } \\
\text { et al. } \\
(2009)\end{array}$ & USA & $0-12$ years & - & 46 & $\begin{array}{c}\text { Normal } \\
\text { HFNC (46) }\end{array}$ & $\begin{array}{l}\text { Standard low } \\
\text { flow oxygen, } \\
\text { before receiving } \\
\text { HFNC (46) }\end{array}$ & $\begin{array}{l}\text { Respiratory distress } \\
\text { and hypoxemia }\end{array}$ & $<0.05$ \\
\hline \multicolumn{9}{|c|}{ In children with bronchiolitis } \\
\hline $\begin{array}{l}\text { Mayfield } \\
\text { S et al. } \\
(2014)\end{array}$ & Australia & $<12$ months & - & 94 & $\begin{array}{l}\text { HFNC } \\
(61)\end{array}$ & $\begin{array}{l}\text { Standard low } \\
\text { flow oxygen }\end{array}$ & $\begin{array}{c}\text { Respiratory rate, } \\
\text { heart rate and ICU } \\
\text { admission from } \\
\text { emergency } \\
\text { department }\end{array}$ & $<0.05$ \\
\hline $\begin{array}{l}\text { Mckiernan } \\
\text { et al. } \\
(2010)\end{array}$ & $\begin{array}{c}\text { New } \\
\text { Zealand }\end{array}$ & $<24$ months & - & 115 & $\begin{array}{l}\text { HFNC- } \\
\text { A (58) }\end{array}$ & $\begin{array}{l}\text { Standard low } \\
\text { flow oxygen due } \\
\text { to HFNC-NA (57) }\end{array}$ & $\begin{array}{l}\text { Rates of intubation } \\
\quad \text { (5 vs. 13) }\end{array}$ & $<0.05$ \\
\hline
\end{tabular}

MCS = modified comfort score; HFNC-A = high flow nasal cannula-available; HFNC-NA = high flow nasal cannula-not available;

Studies from New Zealand and USA used chart analysis and evaluated the use of HFNC oxygen therapy compared to historical control of conventional low flow oxygen therapy in children with clinical features consistent with severe pneumonia and hypoxemia. The study from Australia was prospectively done and evaluated the efficacy of HFNC oxygen therapy compared to conventional low flow oxygen therapy in children with bronchiolitis. Children treated with HFNC therapy compared to those who did not receive HFNC therapy in both the studies had better outcome (Table 3). 
Risk of bias within studies

Table 4: Risk of bias assessment within studies

\begin{tabular}{|c|c|c|c|c|c|c|}
\hline Authors & $\begin{array}{c}\text { Random } \\
\text { sequence } \\
\text { generation } \\
\text { (selection bias) }\end{array}$ & $\begin{array}{c}\text { Allocation } \\
\text { concealment } \\
\text { (selection bias) }\end{array}$ & $\begin{array}{l}\text { Blinding of } \\
\text { participants } \\
\text { and personnel } \\
\text { (performance } \\
\text { bias) }\end{array}$ & $\begin{array}{l}\text { Blinding of } \\
\text { outcome } \\
\text { assessment } \\
\text { (detection } \\
\text { bias) }\end{array}$ & $\begin{array}{c}\text { Incomplete } \\
\text { data (attrition } \\
\text { bias) }\end{array}$ & $\begin{array}{l}\text { Selective } \\
\text { reporting } \\
\text { (reporting } \\
\text { bias) }\end{array}$ \\
\hline Daga $S$ et al. & - & - & - & - & + & + \\
\hline Heuvel et al. & - & - & - & - & + & + \\
\hline Yagui et al & + & + & - & - & + & + \\
\hline Courtney et al. & + & - & - & - & + & + \\
\hline Tagare et al. & + & + & - & - & + & + \\
\hline Buckmaster et al. & + & + & - & - & + & + \\
\hline Koyamaibole et al. & - & - & - & - & + & + \\
\hline Liptsen et al & + & + & - & - & + & + \\
\hline Wilson PT et al. & + & + & - & - & + & + \\
\hline Kinikar et al. & - & - & - & - & + & + \\
\hline Spentzas et al. & - & - & - & - & + & + \\
\hline Mayfield S et al. & - & - & - & - & + & + \\
\hline Mckiernan et al. & - & - & - & - & + & + \\
\hline
\end{tabular}

Table 4 shows the risk of bias assessment. Among a total of thirteen included studies in this review, six were randomized trials. All presented adequate random sequence generation but only five reported adequate allocation concealment. Another seven studies were case-control without any random sequence with the risk of selection bias. None of the twelve studies under our review were blinded due to the nature of the interventions, thus there is always a risk of performance bias. Moreover, outcome assessment was also not blinded which might carry a risk of detection bias. None of the studies described any measures that have been taken against these potential biases. The table also shows that the attrition rates were reported and considered acceptable in all the studies. All studies used an intention-to-treat principle for statistical analyses.

\section{Discussion}

Bubble CPAP: The review provides some evidence that BCPAP is effective in improving severe respiratory distress, improving respiratory vital signs, and reducing the use of mechanical ventilation (MV) in children $0-28$ days old ${ }^{63,64}$ as well as in older children ${ }^{59,60}$. However, there were only two studies from developing countries involving older children which evaluated the effect of BCPAP 59,60 . A recently conducted RCT in Ghana in older children ${ }^{59}$ observed significant decrease in respiratory rate (primary outcome) in children with hypoxemia and respiratory distress receiving
BCPAP immediately after admission compared to those not receiving BCPAP immediately after admission for one hour (comparison group received LF oxygen therapy for the initial one hour followed by BCPAP). This study involving 4 rural hospitals in Ghana was stopped after the enrolment of a total of only 69 patients in both the groups (Table 2) because of the achievement of the predetermined significance value $(\mathrm{p}<0.001)$. BCPAP used by the study was low cost and successfully handled by the local nurses. Another study done in India in older children, observed significant reduction of hypoxemia and respiratory rate among the children who received BCPAP compared to same patients who received conventional oxygen before receiving BCPAP, although the sample size was very small (Table 2). This study mainly involved children with influenza like illness with hypoxemia $^{60}$.

In preterm neonates (0-28 days old), the observation of lack of difference in comparing main outcome variables between BCAP and MV in three RCTs ${ }^{61,62,65}$, two of them done in developing countries, one each in Brazil ${ }^{62}$ and India ${ }^{65}$, underscore the importance of the use of BCPAP in newborn period in developing countries with limited resources. A difference in BCPAP compared to MV driven CPAP is that the BCPAP is highly flow dependent whereas MV driven CPAP is flow independent. However, considering the need for skilled manpower, training, costs, and invasive nature of MV driven CPAP, BCPAP is non-invasive, very cheap, more user 
friendly, does not need special training and can be handled by nurses or health workers at hospitals in resource limited settings especially in the Thana or district level.

Among the two other studies in children 0-28 days with large sample who had better outcome with BCPAP, one RCT done in Australia involving newborn and receiving BCPAP had significantly lower treatment failure ${ }^{64}$, and another from Fiji involved neonates as historical control and receiving BCPAP had the significant reduction of requirement of $\mathrm{MV}{ }^{63}$. However, both the studies have been conducted in developed country set ups with high resources and the age of the children in both the studies was below 28 days and the evidence of affectivity of BCPAP in beyond this age group is yet to be proven.

Observation of failure to show better outcome of BCPAP in two other studies done in 0-28 days old children ${ }^{66,67}$ may question the overwhelming effectiveness of BCPAP even in neonates among the nine relevant studies in our review. This might be due to small sample in two groups. However, there might have other contributing factors especially in study done by Liptsen et al. ${ }^{66}$ where study results had been obtained within short time span (5 to 10 minutes of stabilization period) and authors also raised the issue that it was not possible to draw conclusions about the long term clinical importance from statistically insignificant short term physiological studies. Study done by Heuvel at al. ${ }^{67}$ had different primary outcome which was not relevant to our review but sub-analysis of their study, relevant to our review, revealed that death in both the groups were comparable. This might be also due to small sample size (Table 2) in the group of patient who received BCPAP compared to LF therapy $[2 / 5$ (40\%) vs. 14/20 (70\%); 95\% CI=0.02-3.0).

\section{Limitation of this review}

Marked heterogeneity is one of the main limitations of this review. There was heterogeneity between study populations and methodologies, including differences in sample size, gestational age, variations in disease severity, variations of comparison groups (such as conventional low flow oxygen, head box oxygen, ventilator driven CPAP, variable flow nasal CPAP, historical control, and no CPAP), and primary outcomes (such as treatment or CPAP failure, success of BCPAP, need for mechanical ventilation, work of breathing, change in respiratory rate at one hour of enrolment, improvement of vital signs, hypoxemia and death). The review did not identify any study involving children specifically with severe pneumonia and hypoxemia comparing the efficacy of BCPAP therapy with LF therapy and/or HFNC.

HFNC: Three relevant studies involving mostly older children receiving HFNC had better outcome compared to those receiving LF therapy, however all these studies were conducted in developed countries. We did not identify any studies conducted in developing countries involving the children receiving HFNC therapy compared to LF therapy. One of these two studies done in the USA by Spentzas T et al. used modified comfort score (MCS) as the primary outcome which included the response to signs of respiratory distress in addition to a number of other physical parameters ${ }^{70}$. Primary outcome of the study also involved improvement in oxygen saturation. The study children receiving HFNC therapy observed to have significant improvement in signs of respiratory distress and oxygen saturation. Assessment of MCS in improving the signs of respiratory distress has already been observed in a number of previously conducted studies ${ }^{72-74}$. Another study among these two, conducted in New Zealand by McKiernan $\mathrm{C}$ et al. used the rates of intubation as the main outcome variable and observed significant reduction in the rate of intubation among the children receiving HFNC therapy ${ }^{69}$. On the other hand, significant reduction of ICU admission and reduction in respiratory rate were observed in the third relevant study in our review, prospectively conducted in a hospital emergency department in Australia by Mayfield et al. ${ }^{71}$. From these studies the authors concluded that HFNC oxygen therapy provides a well tolerated means of respiratory support in children with respiratory distress and improves different parameters of increased respiratory effort in order to prevent intubation and mechanical ventilation in developed countries. However retrospective nature of two of these three studies and lack of randomization are the main limitations. The lack of measurement of actual PEEP in HFNC therapy is another limitation of the studies.

Conclusions: There is evidence that BCPAP oxygen therapy is effective in managing neonates with respiratory distress and hypoxemia in developed countries, however, the evidence is limited in regard children beyond newborn especially in developing countries. Although, HFNC therapy may be effective in managing children with respiratory distress and hypoxemia in developed countries, studies of the use of HFNC therapy are also limited and do not allow firm conclusions to be made. However, none of the studies of BCPAP or HFNC therapy specifically included children with severe pneumonia and hypoxemia beyond the neonatal period, and evaluated treatment failure or mortality.

\section{Reference}

1. Adams JA, Osiovich H, Goldberg RN, Suguihara C, Bancalari E. Hemodynamic effects of continuous negative extrathoracic pressure and continuous positive airway pressure in piglets with normal lungs. Biol Neonate 1992; 62(2-3): 69-75.

2. Onyango FE, Steinhoff MC, Wafula EM, Wariua S, Musia J, Kitonyi J. Hypoxaemia in young Kenyan children with acute lower respiratory infection. Bmj 1993; 306(6878): 612-5.

3. Duke T, Mgone J, Frank D. Hypoxaemia in children with severe pneumonia in Papua New Guinea. Int J Tuberc Lung Dis 2001; 5(6): 511-9.

4. Chisti MJ, Duke T, Robertson CF, et al. Clinical predictors and outcome of hypoxaemia among under-five diarrhoeal children with or without pneumonia in an urban hospital, Dhaka, Bangladesh. Tropical medicine \& international health : TM \& IH 2012; 17(1): 106-11.

5. Liu L, Johnson HL, Cousens S, et al. Global, regional, and national causes of child mortality: an updated systematic analysis for 2010 with time trends since 2000. Lancet 2012; 379(9832): 2151-61. 
6. Black RE, Cousens S, Johnson HL, et al. Global, regional, and national causes of child mortality in 2008: a systematic analysis. Lancet 2010; 375(9730): 1969-87.

7. WHO. Pocket book for hospital care of children: guidelines for the management of common illness with limited resources Geneva: World Health Organization 2013.

8. Alexander G, Gerhardt T, Bancalari E. Hyaline membrane disease. Comparison of continuous negative pressure and nasal positive airway pressure in its treatment. Am J Dis Child 1979; 133(11): 1156-9.

9. Marshall A, Pittard M. Use of continuous positive airway pressure (CPAP) in the critically ill--physiological principles. Aust Crit Care 1999; 12(4): 154-8.

10. Pirret AM. Acute care nursing: a physiological approach to clinical assessment and patient care. Auckland: Alison Pirret;. 2005.

11. Higgins JP, Altman DG, Gotzsche PC, et al. The Cochrane Collaboration's tool for assessing risk of bias in randomised trials. Bmj 2011; 343: d5928.

12. Nekvasil R, Kratky J, Penkova Z, Stejskal J. [High frequency "bubble" oscillation ventilation in the neonatal period]. Cesk Pediatr 1992; 47(8): 465-70.

13. Pirret AM, Sherring CL, Tai JA, Galbraith NE, Patel R, Skinner SM. Local experience with the use of nasal bubble CPAP in infants with bronchiolitis admitted to a combined adult/paediatric intensive care unit. Intensive Crit Care Nurs 2005; 21(5): 314-9.

14. Diblasi RM. Nasal continuous positive airway pressure (CPAP) for the respiratory care of the newborn infant. Respir Care 2009; 54(9): 1209-35.

15. Morley CJ, Davis PG. Continuous positive airway pressure: scientific and clinical rationale. Curr Opin Pediatr 2008; 20(2): 119-24.

16. Shah PS, Ohlsson A, Shah JP. Continuous negative extrathoracic pressure or continuous positive airway pressure for acute hypoxemic respiratory failure in children. Cochrane Database Syst Rev 2008; (1): CD003699.

17. Meneses J, Bhandari V, Alves JG. Nasal intermittent positive-pressure ventilation vs nasal continuous positive airway pressure for preterm infants with respiratory distress syndrome: a systematic review and meta-analysis. Arch Pediatr Adolesc Med 2012; 166(4): 372-6

18. Gunlemez A, Isken T. Bubble CPAP must be used with care to avoid harm. Arch Dis Child Fetal Neonatal Ed 2008; 93(2): F170-1.

19. McCollum ED, Smith A, Golitko CL. Bubble continuous positive airway pressure in a human immunodeficiency virus-infected infant. Int J Tuberc Lung Dis; 15(4): 562-4.

20. Sahni R. Bubble CPAP: can we predict success or failure? Indian Pediatr 2010; 47(2): 129-30.

21. Polin RA. Bubble CPAP: a clash of science, culture, and religion. $J$ Pediatr 2009; 154(5): 633-4.

22. Levesque BM, Kalish LA, LaPierre J, Welch M, Porter V. Impact of implementing 5 potentially better respiratory practices on neonatal outcomes and costs. Pediatrics 2011; 128(1): e218-26.

23. Dunn MS, Kaempf J, de Klerk A, et al. Randomized trial comparing 3 approaches to the initial respiratory management of preterm neonates. Pediatrics 2011; 128(5): e1069-76.

24. Narendran V, Donovan EF, Hoath SB, Akinbi HT, Steichen JJ, Jobe AH. Early bubble CPAP and outcomes in ELBW preterm infants. $J$ Perinatol 2003; 23(3): 195-9.

25. Tapia JL, Urzua S, Bancalari A, et al. Randomized trial of early bubble continuous positive airway pressure for very low birth weight infants. $J$ Pediatr 2012; 161(1): 75-80 e1.
26. Gupta S, Sinha SK, Tin W, Donn SM. A randomized controlled trial of post-extubation bubble continuous positive airway pressure versus Infant Flow Driver continuous positive airway pressure in preterm infants with respiratory distress syndrome. J Pediatr 2009; 154(5): $645-50$

27. Yadav S, Thukral A, Sankar MJ, et al. Bubble vs Conventional Continuous Positive Airway Pressure for Prevention of Extubation Failure in Preterm Very Low Birth Weight Infants: A Pilot Study. Indian J Pediatr 2011.

28. Lee KS, Dunn MS, Fenwick M, Shennan AT. A comparison of underwater bubble continuous positive airway pressure with ventilator-derived continuous positive airway pressure in premature neonates ready for extubation. Biol Neonate 1998; 73(2): 69-75.

29. Koti J, Murki S, Gaddam P, Reddy A, Reddy MD. Bubble CPAP for respiratory distress syndrome in preterm infants. Indian Pediatr 2010; 47(2): 139-43

30. Urs PS, Khan F, Maiya PP. Bubble CPAP - a primary respiratory support for respiratory distress syndrome in newborns. Indian Pediatr 2009; 46(5): 409-11.

31. Nowadzky T, Pantoja A, Britton JR. Bubble continuous positive airway pressure, a potentially better practice, reduces the use of mechanical ventilation among very low birth weight infants with respiratory distress syndrome. Pediatrics 2009; 123(6): 1534-40.

32. Kawaza K, Machen HE, Brown J, et al. Efficacy of a Low-Cost Bubble CPAP System in Treatment of Respiratory Distress in a Neonatal Ward in Malawi. PloS one 2014; 9(1): e86327.

33. Martin S, Duke T, Davis P. Efficacy and safety of bubble CPAP in neonatal care in low and middle income countries: a systematic review. Arch Dis Child Fetal Neonatal Ed 2014.

34. Hendriks H, Kirsten GF, Voss M, Conradie H. Is continuous positive airway pressure a feasible treatment modality for neonates with respiratory distress syndrome in a rural district hospital? $J$ Trop Pediatr 2014; 60(5): 348-51.

35. Beggs S, Wong ZH, Kaul S, Ogden KJ, Walters JA. High-flow nasal cannula therapy for infants with bronchiolitis. Cochrane Database Syst Rev 2014; 1: CD009609.

36. Manley BJ, Owen LS, Doyle LW, et al. High-flow nasal cannulae in very preterm infants after extubation. $N$ Engl $J$ Med 2013; 369(15): 1425-33.

37. Mayfield S, Jauncey-Cooke J, Hough JL, Schibler A, Gibbons K, Bogossian F. High-flow nasal cannula therapy for respiratory support in children. Cochrane Database Syst Rev 2014; 3: CD009850.

38. Dysart K, Miller TL, Wolfson MR, Shaffer TH. Research in high flow therapy: mechanisms of action. Respir Med 2009; 103(10): $1400-5$

39. de Winter JP, de Vries MA, Zimmermann LJ. Clinical practice : noninvasive respiratory support in newborns. Eur J Pediatr 2010; 169(7): 777-82.

40. Wilkinson D, Andersen C, O'Donnell CP, De Paoli AG. High flow nasal cannula for respiratory support in preterm infants. Cochrane Database Syst Rev 2012; (5): CD006405.

41. Shoemaker MT, Pierce MR, Yoder BA, DiGeronimo RJ. High flow nasal cannula versus nasal CPAP for neonatal respiratory disease: a retrospective study. J Perinatol 2007; 27(2): 85-91.

42. Saslow JG, Aghai ZH, Nakhla TA, et al. Work of breathing using high-flow nasal cannula in preterm infants. J Perinatol 2006; 26(8): 476-80

43. Bressan S, Balzani M, Krauss B, Pettenazzo A, Zanconato S, Baraldi E. High-flow nasal cannula oxygen for bronchiolitis in a pediatric ward: a pilot study. Eur J Pediatr 2013. 
44. Mayfield S, Jauncey-Cooke J, Bogossian F. A case series of paediatric high flow nasal cannula therapy. Aust Crit Care 2013.

45. Yoder BA, Stoddard RA, Li M, King J, Dirnberger DR, Abbasi S. Heated, humidified high-flow nasal cannula versus nasal CPAP for respiratory support in neonates. Pediatrics 2013; 131(5): e1482-90.

46. Collins CL, Holberton JR, Barfield C, Davis PG. A randomized controlled trial to compare heated humidified high-flow nasal cannulae with nasal continuous positive airway pressure postextubation in premature infants. J Pediatr 2013; 162(5): 949-54 e1.

47. Garcia Figueruelo A, Urbano Villaescusa J, Botran Prieto M, Solana Garcia MJ, Mencia Bartolome S, Lopez-Herce Cid J. [Use of high-flow nasal cannula for non-invasive ventilation in children]. Anales de pediatria 2011; 75(3): 182-7.

48. Miller SM, Dowd SA. High-flow nasal cannula and extubation success in the premature infant: a comparison of two modalities. $J$ Perinatol 2010; 30(12): 805-8.

49. Campbell DM, Shah PS, Shah V, Kelly EN. Nasal continuous positive airway pressure from high flow cannula versus Infant Flow for Preterm infants. J Perinatol 2006; 26(9): 546-9.

50. Woodhead DD, Lambert DK, Clark JM, Christensen RD. Comparing two methods of delivering high-flow gas therapy by nasal cannula following endotracheal extubation: a prospective, randomized, masked, crossover trial. J Perinatol 2006; 26(8): 481-5.

51. Ojha S, Gridley E, Dorling J. Use of heated humidified high-flow nasal cannula oxygen in neonates: a UK wide survey. Acta paediatrica 2013 ; 102(3): 249-53.

52. Manley BJ, Dold SK, Davis PG, Roehr CC. High-flow nasal cannulae for respiratory support of preterm infants: a review of the evidence. Neonatology 2012; 102(4): 300-8.

53. Mayfield S, Jauncey-Cooke J, Bogossian F. A case series of paediatric high flow nasal cannula therapy. Aust Crit Care 2013; 26(4): 189-92.

54. Kallappa C, Hufton M, Millen G, Ninan TK. Use of high flow nasal cannula oxygen (HFNCO) in infants with bronchiolitis on a paediatric ward: a 3-year experience. Archives of disease in childhood 2014; 99(8): 790-1.

55. Sasi A, Malhotra A. High flow nasal cannula for continuous positive airway pressure weaning in preterm neonates: A single-centre experience. J Paediatr Child Health 2014.

56. Lavizzari A, Veneroni C, Colnaghi M, et al. Respiratory mechanics during NCPAP and HHHFNC at equal distending pressures. Arch Dis Child Fetal Neonatal Ed 2014; 99(4): F315-20.

57. Testa G, Iodice F, Ricci Z, et al. Comparative evaluation of high-flow nasal cannula and conventional oxygen therapy in paediatric cardiac surgical patients: a randomized controlled trial. Interactive cardiovascular and thoracic surgery 2014; 19(3): 456-61.

58. Hough JL, Pham TM, Schibler A. Physiologic effect of high-flow nasal cannula in infants with bronchiolitis. Pediatr Crit Care Med 2014; 15(5): e214-9.

59. Wilson PT, Morris MC, Biagas KV, Otupiri E, Moresky RT. A randomized clinical trial evaluating nasal continuous positive airway pressure for acute respiratory distress in a developing country. J Pediatr 2013; 162(5): 988-92.
60. Kinikar A, Kulkarni R, Valvi C, Gupte N. Use of indigenous bubble CPAP during swine flu pandemic in Pune, India. Indian J Pediatr 2011; 78(10): 1216-20.

61. Courtney SE, Kahn DJ, Singh R, Habib RH. Bubble and ventilator-derived nasal continuous positive airway pressure in premature infants: work of breathing and gas exchange. J Perinatol 2011; 31(1): 44-50.

62. Yagui AC, Vale LA, Haddad LB, et al. Bubble CPAP versus CPAP with variable flow in newborns with respiratory distress: a randomized controlled trial. J Pediatr (Rio J) 2011; 87(6): 499-504.

63. Koyamaibole L, Kado J, Qovu JD, Colquhoun S, Duke T. An evaluation of bubble-CPAP in a neonatal unit in a developing country: effective respiratory support that can be applied by nurses. J Trop Pediatr 2006; 52(4): 249-53.

64. Buckmaster AG, Arnolda G, Wright IM, Foster JP, Henderson-Smart DJ. Continuous positive airway pressure therapy for infants with respiratory distress in non tertiary care centers: a randomized, controlled trial. Pediatrics 2007; 120(3): 509-18.

65. Tagare A, Kadam S, Vaidya U, Pandit A, Patole S. A pilot study of comparison of BCPAP vs. VCPAP in preterm infants with early onset respiratory distress. J Trop Pediatr 2010; 56(3): 191-4.

66. Liptsen E, Aghai $\mathrm{ZH}$, Pyon $\mathrm{KH}$, et al. Work of breathing during nasal continuous positive airway pressure in preterm infants: a comparison of bubble vs variable-flow devices. J Perinatol 2005; 25(7): 453-8.

67. van den Heuvel M, Blencowe H, Mittermayer K, et al. Introduction of bubble CPAP in a teaching hospital in Malawi. Ann Trop Paediatr 2011; 31(1): 59-65.

68. Daga S, Mhatre S, Borhade A, Khan D. Home-Made Continuous Positive Airways Pressure Device may Reduce Mortality in Neonates with Respiratory Distress in Low-Resource Setting. $J$ Trop Pediatr 2014; 60(5): 343-7.

69. McKiernan C, Chua LC, Visintainer PF, Allen H. High flow nasal cannulae therapy in infants with bronchiolitis. J Pediatr 2010; 156(4): 634-8.

70. Spentzas T, Minarik M, Patters AB, Vinson B, Stidham G. Children with respiratory distress treated with high-flow nasal cannula. $J$ Intensive Care Med 2009; 24(5): 323-8.

71. Mayfield S, Bogossian F, O'Malley L, Schibler A. High-flow nasal cannula oxygen therapy for infants with bronchiolitis: Pilot study. $J$ Paediatr Child Health 2014.

72. Ambuel B, Hamlett KW, Marx CM, Blumer JL. Assessing distress in pediatric intensive care environments: the COMFORT scale. Journal of pediatric psychology 1992; 17(1): 95-109.

73. Crain N, Slonim A, Pollack MM. Assessing sedation in the pediatric intensive care unit by using BIS and the COMFORT scale. Pediatr Crit Care Med 2002; 3(1): 11-4.

74. Ista E, van Dijk M, Tibboel D, de Hoog M. Assessment of sedation levels in pediatric intensive care patients can be improved by using the COMFORT "behavior" scale. Pediatr Crit Care Med 2005; 6(1): $58-63$ 